\title{
4.10 Впровадження інноваційних технологій у навчання фізики в закладах вищої освіти
}

\subsection{1. Проблеми та особливості застосування інноваційних технологій} в педагогічних закладах вищої освіти

Основними пріоритетами державної політики у сфері вищої освіти на сучасному етапі їі реформування наголошено:

• забезпечення якості вищої освіти;

- інтеграція до європейського простору вищої освіти i наукових досліджень;

- освіта впродовж життя.

Питання забезпечення якості вищої освіти зараз є світовим трендом. Інтернаціоналізація української вищої освіти, входження вітчизняних університетів до Європейського простору вимагає від закладів вищої освіти (3ВО) визнання та дотримання європейських освітніх стандартів, побудови на основі європейських стандартів і рекомендацій власної системи внутрішнього забезпечення якості освіти в університетах.

3 введенням нових стандартів підготовка кваліфікованих спеціалістів, конкурентноспроможних на міжнародному ринку праці, здатних орієнтуватись в суміжних галузях діяльності, готових до компетентної, відповідальної та ефективної діяльності, до постійного професіонального росту, неможлива без впровадження інноваційних технологій, які в практиці навчання є обов'язковою умовою підвищення якості навчання [346].

У проєкті «Стратегія розвитку вищої освіти в Україні на 2021-2031 роки» на основі проведеного аналізу проблем і переваг системи вищої освіти України як іiі слабкі сторони визначено низький рівень залученості до наукової та інноваційної діяльності учасників освітнього процесу, їх вмотивованості, слабка практична підготовка фахівців. Виходячи з цього й зважаючи на глобальні тренди. пріоритетними принципами розвитку вищої освіти в Україні зазначено:

• орієнтація на найвищі наукові досягнення; 
• орієнтація на досягнення найвищої якості освіти.

Інтеграція України у світовий освітній простір вимагає постійного вдосконалення національної системи освіти, пошуку ефективних шляхів підвищення якості освітніх послуг, апробації та впровадження інноваційних педагогічних систем.

Впровадження інноваційних технологій і дистанційного навчання у вищій освіті при цьому визначене як операційна ціль, для досягнення якої потрібно вирішити наступні завдання [347]:

- створення індустрії інноваційних технологій та засобів навчання, що відповідають світовому науково-технічному рівню;

- диджиталізація усіх процесів у системі вищої освіти;

- унормування дистанційного навчання як форми здобуття вищої освіти.

Сутність інноваційної педагогічної діяльності, iї структура та класифікація розглядалися в працях Л.І. Антошкіної, В.А. Сластенина, В.І. Загвязинського, М.М. Поташника, Н.Р. Юсуфбекової, М.Ф. Баймухамедова, І.В. Тимошенкова, Л.І. Даниленко, О.А. Дубасенюк, О.Г. Козлової, І.С. Каленюк, А.І. Пригожина, М.В. Кларіна, А.М. Бронської, Н.І. Клокар. Проблеми, пов’язані з механізмами застосування та впровадження педагогічних нововведень вивчали I.М. Дичківська, С.А. Безгородько, І.Ф. Ісаев, Г.С. Беккер А.Г. Кругліков, С.Д. Поляков, А.А. Орлов, проблеми творчого саморозвитку вчителя, педагогічного колективу в умовах інноваційної діяльності, труднощів, стимулів і перешкод - В.А. Кан-Калик, Н.Ш. Чинкина, А.В. Попов, В.П. Кваша, К.А. Алібай, О.Г. Хмарка, А.В. Лоренс. Велика частина досліджень присвячена проблемам підготовки студентів університетів до інноваційної діяльності, до застосування інноваційних технологій навчання в школі (Н.М. Анісімов, С.Д. Поляков, Н.А. Щербаков, В.С. Пилаєва, В.Е. Тамарін, С.П. Морозов, І.В. Штих та ін.).

Дослідженнями проблеми розробки, аналізу та впровадження інноваційних технологій у навчання фізики в середній та вищій школі займалися В.Ю. Биків, П.С. Атаманчук, С.П. Величко, В. Слободчиков, В.Ф. Заболотний, М.I. Жалдак, О.І. Іваницький, Н.В. Леонова та інші. Водночас багато дослідників, 
такі як В.С. Кагерманьян, А.Я. Савельєв, О. Голубєва, відзначають, що структура курсу фізики у вищій школі не піддавалася перегляду, принаймні, протягом останніх п'ятдесяти років. Весь цей час модернізація відбувалася лише за рахунок механічного додавання нового матеріалу без оцінки і обліку його впливу на осмислення фізичної картини світу в цілому.

Аналіз сучасних досліджень проблеми педагогічних інновацій показує, що питання їх впровадження і реалізації залишається досить актуальним і широко обговорюваним. У сучасній освіті не існує певної і загальноприйнятої концепції інноваційної діяльності. Крім того, педагогічні інновації розглядаються частіше 3 прикладної точки зору, як результат освітньої практики. Проте, незважаючи на відсутність єдиної концепції завдання, впровадження інновацій ставлять перед собою більшість освітніх установ.

Основними цілями інноваційного навчання є наступні:

- розвиток критичного мислення;

- проблемне навчання;

- диференційований підхід до навчання;

- створення ситуацій успіху.

У теорії та практиці педагогічної освіти накопичено чималий банк активних, практико-орієнтованих форм, методів і технологій навчання, що враховують закономірності розвитку, рівень, особливості тих, хто навчається, їх готовність до самостійного набуття знань i ефективного використання в практичній діяльності. Існує безліч освітніх та навчальних технологій, заснованих на інноваційних підходах. Вони розрізняються по цілях, завданнях, структурі, специфіці здійснення конкретного виду педагогічної діяльності, організаційній формі, методиці навчання, передбаченій мірі активності суб’ єктів освітнього процесу, виду взаємодії викладача і навчального контингенту тощо.

До відомих інноваційні технології відносяться технологія проблемного навчання (А.М. Матюшкін, С.Л. Рубіншгейн, М.И. Махмутов, И.Я. Лернер); технологія модульного навчання (Т. І. Шамова, П.І. Третяков), технологія розвиваючого навчання (В. В. Давидов, Л. В. Занков), технологія навчання за 
В.Ф. Шаталовим, технологія навчання «Кластерн», технологія групової пошукової діяльності Дж. Гордона, мультимедіа технології навчання та багато інших.

Вибір освітніх технологій, особливості методики їх застосування визначаються, зокрема, цільовою аудиторією. Так організація освітнього процесу в середній школі й вищих навчальних закладах потребують різних підходів, що обумовлено наступними факторами:

1) особливостями організації освітнього процесу в закладах вищої освіти, які детально розглянуте у Законі України «Про вищу освіту»;

2) відмінностями в цілях навчання: спрямованості навчання у вищій школі на формування у студентів професійного мислення, здатності до майбутньої професійної діяльності в галузі обраної професії;

3) відповідними відмінностями в змісті освіти: залежністю складу навчальних дисциплін та їх змісту від професійної спрямованості; збільшенням обсягу навчального матеріалу з профільних дисциплін тощо;

4) 3 вимогою більш глибокого поєднання навчання 3 науководослідницькою роботою студентів у порівнянні з учнями середньої школи;

5) з віковими відмінностями здобувачів вищої освіти, зокрема, з більшою здатністю до самостійного опанування навчальних дисциплін, до абстрактного мислення, зростанням ролі уваги в пізнавальному процесі, активізації розвитку всіх видів почуттів, зокрема, відчуття особистості тощо.

Професійний розвиток особистості майбутніх педагогів здійснюється засобами цілеспрямованої, систематичної, педагогічно організованої підготовки в процесі діяльності та спілкування в освітній сфері. Становлення студента як суб'єкта освітньої сфери проходить шляхом включення його в педагогічний процес, що має творчу спрямованість та забезпечує умови для набуття ним досвіду наукової та творчої діяльності, а саме:

- професійно-творчий розвиток студентів, оволодіння ними досвідом наукової та творчої роботи; 
- формування мотиваційно-споживчої сфери їх особистості з установкою на науковий пошук та педагогічні інновації, розвиток здатності створювати атмосферу творчості, пошуку авторських рішень;

- індивідуалізація, підтримка самобутності особистості, що дозволяє студентам реалізувати ідеї та вирішення педагогічних проблем у практиці педагогічної роботи.

Здійснення цих напрямів пов'язане 3 моделюванням та реалізацією цілеспрямованої, систематичної підготовки у проблемно-інноваційній сфері діяльності. Зміст іiі покликаний розкривати сутність, виховний потенціал, функції освітнього середовища як фактору формування професійного вигляду майбутнього педагога та достатнього рівня його готовності до створення атмосфери наукового пошуку та педагогічної творчості у майбутній професійній діяльності.

Джерелом та результатом ефективного професійного розвитку професійного розвитку майбутнього вчителя виступає освоєння нових видів діяльності, нових освітніх сфер та нових відносин, у тому числі і проблемноінноваційної сфери педагогічної діяльності.

На становлення творчої особистості великий вплив має проблемноінноваційна сфера іiї діяльності. Проектування проблемно-інноваційної сфери діяльності в процесі підготовки майбутніх вчителів виступає важливим фактором розвитку їх творчих здібностей, формування творчого стилю діяльності та активної професійної позиції, без чого неможлива педагогічна творчість та педагогічні інновації. Ця сфера забезпечує кожному студенту можливість нестандартно діяти, самостійно робити вибір способів вирішення навчальних проблем, налаштування на перспективу професійного саморозвитку, самоствердження у професійній діяльності та досягнення професійного успіху. Вона орієнтує на створення у вищій школі такої обстановки, яка б стимулювала кожного студента на нестандартність дій, пошук творчого виходу із проблемних ситуацій. 
Застосування інноваційних технологій у освітньому процесі з фізики в педагогічних 3ВО має на меті ще й наступні цілі:

- показати студентам можливості застосування інноваційних технологій у навчанні фізики на різних рівнях освіти;

- продемонструвати можливості адаптації застосованих у ЗВО технологій до урочної та позаурочної діяльності в школі, чому, зокрема, сприятиме приведення аналогій та встановлення зв'язків зі шкільним курсом фізики;

- залучити студентів до творчої діяльності з аналізу ефективності різних інноваційних технологій, задля чого освітній процес повинен бути побудований таким чином, щоб студенти мали можливість не тільки навчатися за інноваційними технологіями, а й набували модельний досвід їх застосування в навчальному процесі.

Як ключові тенденції, що прискорюють впровадження інноваційних освітніх технологій у сучасні сектори вищої освіти, українські та міжнародні експерти відмічають наступні:

1. Підвищення уваги до вимірювання навчання.

2. Розширення сфери використання моделей зміманого навчання.

3. Переформатування навчальних просторів, оновлення навчального середовища, реалізація різних форми віддаленої роботи, розвиток навичок роботи в циифровому світі.

4. Впровадження проблемно-, проектно-, дослідницько-орієнтованого навчання, які мотивують студентів, забезпечують усвідомлення ними чіткого зв'язку між навчальним планом і реальним світом довкола; розвиток нових технологій, таких як перевернуте навчання.

5. Сприяння адаптації до постійно змінюваних економічних потреб суспільства, синергія між освітою, наукою та інноваціям.

\subsection{2. Проблемне навчання}

Проблемне навчання - це система прийомів, що пробуджує інтерес студентів до пошуку розв'язання проблем, на відміну від механічного засвоєння 
готових знань, включення механізмів мислення шляхом створення проблемних ситуацій.

Проблемна ситуація - стан інтелектуального утруднення, необхідність робити вибір, приймати рішення, вирішити утруднення, що виникле, включати мислення й тим самим активізувати навчальний процес.

Проблемне навчання включає як творче засвоєння знань, так і оволодіння способами, прийомами пізнання, отже вчить студентів мислити, включаючи емоційно-психологічну мотивацію, справляє позитивний вплив на загальний розвиток особистості.

3 формами і рівнем проблемного навчання пов’язані й відповідні методи:

1) метод проблемного викладу, коли викладач демонструє зразок постановки проблеми, шляхів, засобів, прийомів проблемного мислення i вирішення поставленої пізнавальної задачі;

2) евристичний метод - частково-пошуковий, коли викладач створює проблемну ситуацію, формулює проблему i залучає студентів до процесу іï розв’язання;

3) дослідницький метод - найскладніший рівень самостійної роботи студентів, коли студенти самі бачать протиріччя, формулюють проблему та іiі розв’язують.

Проблемно-оріснтоване навчання або PtBL (Problem Based Learning) навчання на основі проблеми - навчальний підхід, заснований на процесі пошуку вирішення спеціально сформульованої проблеми, для розв’язання якої здобувачам освіти потрібно звертатися до теоретичного матеріалу. У такий спосіб, викладач не дає готову інформацію, а задає проблему і виступає в ролі помічника, консультанта, модерує дискусію щодо розв’язання проблеми [348].

Проблемно-орієнтоване навчання може здійснюватися як:

- навчання через дію - проблема і рішення повинні виражатися в діях, наприклад, створення нового формату підручника - PBL (Project Based Learning), навчання на основі проекту (метод проектів) [349]; 
- навчання на місці - слухачі повинні вчитися вирішувати проблему не в аудиторії, а в тому місці, де вона виникає, наприклад в компанії, на заводі, в лікарні, в школі;

• навчання на кейсах.

До переваг технологій проблемно-орієнтованого навчання можна віднести наступне:

- правильно сформ ульована проблема затягує слухачів у процес іiі розв'язання;

- групова дискусія на занятті підвищує мотивацію і дозволяє почути думку інших;

- здобувачі набувають навички самостійно шукати теоретичний матеріал $\mathrm{i}$ працювати з ним, оцінювати джерела на достовірність, самостійно розв'язувати проблеми;

- здобувачі на практиці уявляють, де їм можуть знадобитися одержані знання.

Головним недоліком моделі є те, що незацікавлені в проблемі або не готові до такого виду роботи студенти можуть випасти 3 процесу обговорення $\mathrm{i}$ навчання.

\subsection{3. Специфіка та завдання методу Case-study при навчанні фізики} в педагогічних $3 B 0$

До чисельних інноваційних методів навчання, що базуються на створенні проблемних ситуацій, відноситься метод кейсів (case-study).

Кейсом у науковій літературі називають опис ситуації і комплекс завдань до нього, які є ядром, дидактичним супроводом методу проблемних ситуацій (кейс-методу).

Метод кейс-стаді може бути названий методом аналізу конкретних ситуацій. Суть методу полягає в наступному: для організації навчання здобувачам освіти пропонують осмислити конкретну ситуацію, змодельовану або реальну, опис якої одночасно відображає не тільки будь-яку практичну проблему, а й актуалізує певний комплекс знань, який необхідно засвоїти при 
розв’язанні даної проблеми. При цьому ти, хто навчається, повинні проаналізувати ситуацію, розібратися в суті проблем, запропонувати можливі рішення і вибрати найкраще з них.

Однією з головних вимог, що пред’являються до кейсів, та їх відмітною особливістю є відсутність єдиного правильного рішення, що дозволяє побачити неоднозначність розв'язання проблеми в реальному житті, вимагає формування умінь оцінювати запропоновані варіанти, прогнозувати результати, вибирати оптимальне рішення. Кейс-метод орієнтований на постановку питань, в той час як інші методи - на пропоновані рішення. В структурі кейса часто відсутній ряд питань, на які необхідно давати відповіді. Замість цього студенту слід цілком осмислити ситуацію, викладену в кейсі, самому виявити проблему і питання, які потребують вирішення. Таким чином забезпечується розвиток самостійності та ініціативності, вміння орієнтуватися в широкому колі питань, пов’язаних 3 різними аспектами професійної діяльності. Метод спрямований не стільки на освоєння конкретних знань, або умінь, скільки на розвиток загального інтелектуального і комунікативного потенціалу студента і викладача.

Реалізація навчання за технологіями, грунтованими на методі кейс-стаді, завдання досить складне, яке вимагає не лише попередньої роботи по відбору навчального матеріалу та розробці самих кейсів, але й можливості їх ефективного використання: часу, що виділяється на вивчення дисципліни, навчально-методичного забезпечення, попередніх знань, навичок самостійної роботи, міждисциплінарних зв’язків.

Кейс-метод тільки розпочинає впроваджуватися в систему фізичної освіти, тому розробка, обгрунтування та апробація теоретичних і методичних аспектів цього методу на сьогодні є актуальною проблемою. Основна функція кейсметода у навчанні фізики в ЗВО - навчити студентів розв'язувати неконструйовані проблемні задачі 3 різними контекстами на основі фундаментальних фізичних знань, які повинні стати опорою при формуванні загальних і спеціальних професійних компетентностей. 
В структурі кейса виділяють два основних розділи: ситуацію та завдання. Найбільш доцільно використовувати такі його розділи: ситуація, завдання, допоміжна інформація, критерії оцінювання [350].

Розділ «Ситуація»є описом реальної (або реально-можливої) проблеми, що вимагає від студента засобами предмета фізики опанувати нове знання й відшукати новий спосіб розв'язання.

Розділ «Завдання» уявляє систему питань і завдань різного рівня, кожне 3 яких повинно дає свій внесок у розуміння і рішення ситуаційної задачі та формування нових уявлень щодо предметних знань і вмінь.

Розділ «Допоміжна інформація» може містити посилання на навчальну та наукову літературу, адреси тематичних веб-ресурсів, таблиці, опорні схеми, методичні рекомендації та інші матеріали. Об'єм допоміжної інформації не повинен бути надмірним, щоб не обмежувати студенту свободу вибору джерела інформації і самостійності пізнавальної діяльності.

Розділ «Критерії оцінювання» знайомить студентів 3 вимогами до якості розв'язання ситуації, допомагає їм об'єктивно оцінювати свої досягнення, мотивує до більш відповідальної роботи над кейсом. Критерії містять наступні параметри:

- володіння понятійним апаратом фізики;

- розуміння змісту фізичних явищ і законів, уміння застосовувати їх на практиці;

- логічність і структурованість розв'язання;

- повнота аналізу та аргументованість висновків;

- самостійність і оригінальність рішення.

При розробці кейса для студентів педагогічного університету слід враховувати, що основним завданням майбутніх вчителів фізики є освітня діяльність. Тому головний акцент при формулюванні проблеми, на постановку якої викладач націлює студентів, повинен бути зроблений на пошук найбільш ефективного, яскравого і наочного пояснення ситуації, зв’язаної с цією 
діяльністю, на зв’язку між матеріалом, що вивчається, зі шкільним курсом фізики.

Джерелами проблемних ситуацій для розробки навчальних кейсів 3 фізики можуть бути описані демонстраційні досліди, в яких результати не відповідають прогнозованим. Наприклад, в дослідах по електризації на результат експерименту можуть істотно впливати такі фактори як стікання заряду при високій вологості, електризація по індукції сусідніх тіл. Ефективним в навчанні за кейс-технологією в подібному випадку може буде виділення групи найбільш активних студентів, яких викладач попередньо знайомить 3 експериментом i проблемами, що виникають при демонстрації. Потім студенти висувають свої пропозиції розв’язання проблем для обговорення в групі.

Для формування навичок наукового дослідження ефективні кейси, які імітують структуру і процес наукового дослідження, застосування тих чи інших методів до розв'язання завдань. Як основу для розробки таких кейсів можна використовувати ситуації, що виникають при проведенні лабораторних занять, при виконанні студентами експериментальної частини курсових і дипломних робіт. При розгляді ситуацій, зв'язаних 3 експериментом, формулювання проблеми може відноситись до вдосконалення техніки або методики проведення експерименту, можливості врахування факторів, що впливають на результати експерименту, заміні досліду іншим.

Ще одним джерелом кейсів можуть служити матеріали, що публікуються в мережі Інтернет і містять фізичні похибки. У такому разі недоліки можуть бути перетворені на переваги завдяки формуванню в студентів критичного відношення до інформації, навичок іiї оцінювання.

Кейс-метод можна представити як складну систему, в яку залежно від ролі кейса в процесі навчання можуть бути інтегровані інші, простіші методи пізнання, такі як моделювання, системний аналіз, проблемний метод, дискусія, уявний експеримент, «мозковий штурм», методи опису, класифікації, інцидентів, проектів, ігрові методи тощо. 
Як показує аналіз літературних джерел, у навчанні фізики в вищій школі, зокрема в педагогічних закладах, кейс-технології застосовуються доволі рідко, переважно при розгляданні окремих тем або питань. Пояснюють це специфікою самої дисципліни, у якій значне місце займають фундаментальні знання про явища природи і матеріальні об'єкти. Кейс-технологія ж призначена для розв'язання проблем прикладного характеру, безпосередньо пов'язаних 3 професійною діяльністю [351]. Але, якщо простежити історію розвитку фізики, практично на кожному етапі нові винаходи, відкриття, теорії з'являлися завдяки проблемним ситуаціям, які потрібно було розв'язати, і які мали не одне, а різні способи й шляхи розв'язання. Щодо прикладного характеру кейс технологій, у роботі викладача або вчителя школи часто виникають проблеми, зв'язані 3 навчанням фізики, які він повинен вміти розв'язувати, такі як необхідність розробки чи вдосконалення методики експерименту, що буде враховувати умови, у яких він виконується, особливості застосованого обладнання; пошук нових прийомів навчання при утрудненнях сприймання інформації студентами тощо.

Опитування студентів показує, що вони дають методам кейс технологій високу оцінку, проте зауважують, що не готові як до навчання за таким методом, так і до його впровадження у своїй професійній роботі. Тобто така технологія, на їх думку, яку висловлюють і більшість дослідників, потребує відповідної підготовки студентів починаючи 3 перших курсів, що вимагає не тільки детальної розробки кейсів і завдань до них, але й структурних змін у організації навчального процесу.

\subsection{4. Інноваційні методи та прийоми асоціативного навчання}

Під час зіткнення 3 проблемною ситуацією (завданням) той, хто навчається, відчуває, що для іï розв'язання йому не вистачає чогось дуже важливого. Саме розв'язання виступає як пошук відсутньої ланки в ланцюжку: завдання - усвідомлення проблеми - поява асоціацій і поява припущень перевірка припущень - виключення непідтверджених припущень - виникнення i перевірка нових припущень - розв'язання задачі. Спонукання робити 
порівняння, зіставляти нові факти, приклади і положення з тим, що було відомо раніше $\epsilon$ ефективним прийомом створення проблемної ситуації. Асоціативні зв'язки у даному випадку використовуються не для запам'ятовування інформації, а як евристичні прийоми (методи) активізації творчості, нестандартного мислення, ненаправленого пошуку. Вони спрямовані на актуалізацію «прихованих» знань для створення нових продуктів (нових знань, ідей, досліджень тощо). Асоціативно-образне мислення є основою творчого процесу.

На застосуванні асоціативних зв'язків базується багато інноваційних методів навчання - методи асоціативних ланцюжків та кущів, сенкан (синвейн), метод фокальних об’єктів, метод ментальних карт, метод кроссенсів, метод аналогій, метод синектики та інші - у яких реалізуються основні принципи інноваційного навчання:

• креативність (орієнтація на творчість);

- засвоєння знань в системі;

• нетрадиційні форми занять;

- використання наочності.

Метод асоціативних ланцюжків. Ланцюжок асоціацій являє собою сукупність понять, де кожне наступне пов'язано не з основним поняттям, а 3 попереднім.

Два навіть зовсім не пов'язані об'єкти або слова можуть бути об'єднані в єдине ціле за допомогою зв'язку таким чином, щоб при виникненні в пам'яті людини одного відразу було відтворено друге, якого бракує. Ланцюжок неконтрольованих, випадкових асоціацій допомагає зазирнути в підсвідомість людини і зрозуміти корінь його проблем. Створюючи незвичайні асоціації можна активізувати творчі здібності, розвинути образну пам'ять, асоціативне мислення за допомогою спеціальних вправ.

Наприклад, під час заняття 3 дисципліни «Інноваційні технології у навчанні фізики» студентам магістратури спеціальності 014 Середня освіта (Фізика) було дано завдання на створення асоціативних ланцюжків, мета якого 
сформувати в студентів здатність встановлювати між двома словами або об'єктами зв'язок, який створює 3 предметів, що не мають між собою нічого спільного, єдине ціле.

Завдання 1. Придумайте два не пов’язаних між собою слова, перше з яких є початком ланцюжка, а друге - кінцем, та побудуйте асоціативний ланцюжок 3 п’яти слів, який пов'яже між собою перше і останнє слово.

Для виконання завдання використовувалась онлайн-дошка Padlet. Варіанти створених студентами ланцюжків приведено на рис. 1.

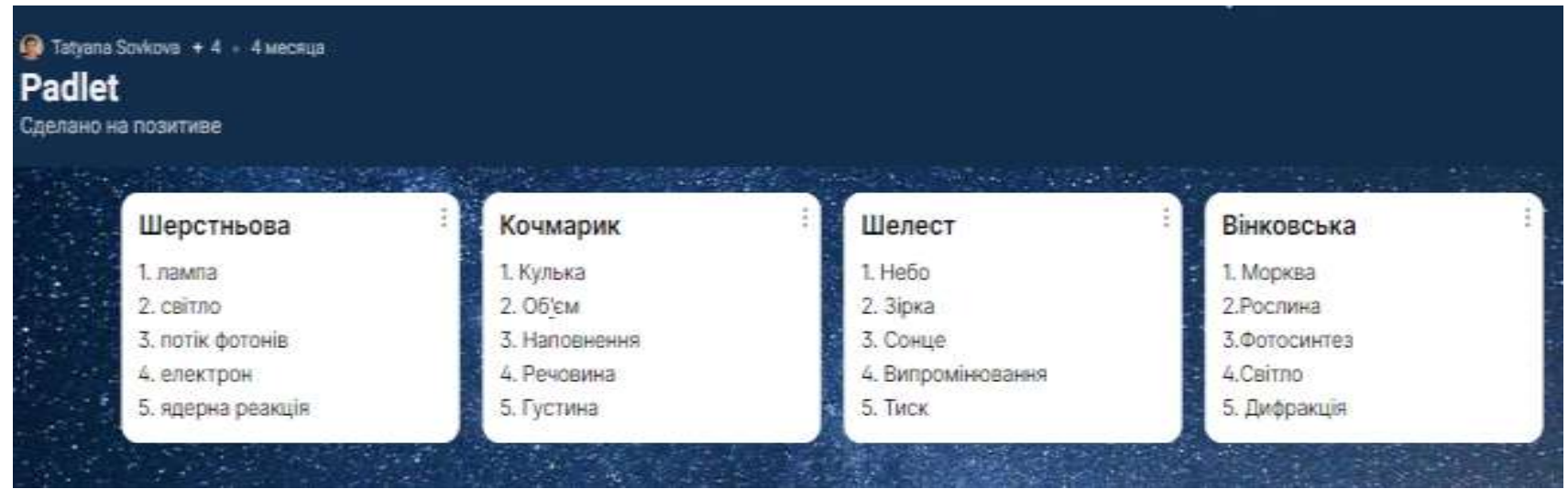

Рисунок 1. Вправа на побудову асоціативного ланцюжка

Наступне завдання може бути на побудову більш складних асоціативних ланцюжків, які пов’язують різні теми, розділи фізики, або ланцюжки, що встановлюють міжпредметні зв’язки. Прикладом таких завдань може бути побудова ланцюжка, який відповідатиме переходу по схемі:

механіка $\rightarrow$ молекулярна фізика та термодинаміка $\rightarrow$ електрика та магнетизм $\rightarrow$ оптика $\rightarrow$ атомна та ядерна фізика

Перше слово може задати викладач, проаналізувавши можливі варіанти створення ланцюжка. Наприклад:

гіперболічна траєкторія (графік руху, графік процесу) $\rightarrow$ ізотерма (температура, вимірювання) $\rightarrow$ термопара (прилад, подвійне) $\rightarrow$ біпризма (інтерференція, спектр) $\rightarrow$ теорія Бора (спектр атому водню)

Метод фокальних (випадкових) об’єктів. Основою методу є асоціативний пошук і евристичні властивості випадковості. Це метод пошуку нових ідей і характеристик об'єкта на основі приєднання до нього властивостей 
інших об'єктів, обраних випадково. Обирається об'єкт, який необхідно вдосконалити. Потім рандомним чином до нього підбирається кілька випадкових іменників (об'єктів). Їх ознаки або властивості переносяться на вихідний об'єкт, який знаходиться «у фокусі» дій. Саме тому метод отримав назву фокальних або випадкових об'єктів.

Найчастіше метод фокальних об'єктів застосовується для пошуку інноваційних та незвичайних рішень. Наприклад, метод часто використовується в теорії розв'язання винахідницьких завдань, 3 метою реконструювання, модифікації пристроїв і технологій.

Наведемо приклад виконання завдання, яке студенти магістратури виконували із застосуванням технології мозкової атаки.

\section{Завдання 2.}

1. Обрати об’єкт, який потрібно перетворити (удосконалити).

2. Обрати три-чотири довільних (випадкових) об’єкта.

3. Скласти списки характерних ознак цих випадкових об'єктів (чим ширше охоплення, тим краще).

4. Спираючись на вільні асоціації сформулювати ідеї, щодо можливості приєднати до фокального об'єкту ознаки випадкових об'єктів.

5. Оцінити отримані ідей і відібрати корисні рішення. (Обговорення і вибір декількох хороших варіантів рішень, що мають свої переваги в різних умовах застосування).

Виконання завдання.

Об’єкт для перетворення - освітлювач (був обраний викладачем, студентам це заздалегідь не повідомлялося).

Випадкові об'єкти та надані їм характерні ознаки (обрано студентами, кожний студент вносив свій об'єкт та пропонував варіанти ознак до усіх об'єктів):

Вікно: скляне, пластикове, дерев’яне, прозоре, відкривається, штори, ізолює, захищає. 
Колесо: кругле, дерев'яне, пластикове, симетричне, крутиться, рухається, котиться, взаємодіє.

Апельсин: помаранчевий, фрукт, їжа, котиться, круглий, солодкий, пориста кожура, складається з дольок.

Озеро: вода, блакитне, глибоке, горне, холодне, гладка поверхня, брижі на поверхні, відбиває та розсіює світло.

Описання кінцевого варіанту об’єкту, прийнятого після сумісного обговорення:

Освітлювач складається 3 декількох окремих дольок, які, в свою чергу, містять джерела (світлодіоди), що випромінюють помаранчеве або блакитне світло. Працює у трьох режимах: 1) включені тільки помаранчеві світлодіоди (теплі), 2) тільки блакитні (холодні), 3) усі джерела. Освітлювач має фільтр, який рівномірно розсіює світло, й шторки, що можуть обмежувати світловий потік. Розташований на дерев'яній основі з чотирма колесами, що дозволяє легко перекочувати освітлювач з одного місця на інше.

Метод «Кроссенс». Слово «кроссенс» означає перехрестя смислів перетин значень. Це асоціативна головоломка, яка уявляє з себе ланцюжок, замкнутий у стандартне поле, що складається як правило з дев'яти квадратів. У кожному квадраті розташовується зображення (картинка, формула, знак), яке має зв'язок із попереднім і наступним, а центральне картинка може об'єднувати всі зображення або деякі з них. Знайти таки зв'язки (асоціативні та логічні) і є завданням до кроссенсу. Кроссенс потрібно читати зліва направо і зверху вниз.

Перед виконанням завдання слід спочатку розібирати, що зображено на кожній картинці. При переході від одного зображення до іншого бажано використовувати не тільки асоціації (аналогії), що безпосередньо стосуються теми кроссенса. Можна спиратися й на асоціації, які пов'язані з життєвим досвідом, на вільні асоціації, що виникають при розгляданні картинок. Оскільки у завданнях такого типу велика роль суб'єктивного сприйняття образів і зображень, то студенти (учні) можуть знаходити різні варіанти зв'язків. Важливо, щоб при цьому вони обгрунтовували свою версію. Усі запропоновані 
зв’язки потрібно проаналізувати 3 точки зору їх вагомості, характеру (поверхневі, глибокі, за формою, за суттю тощо), зв’ язку з іншими дисциплінами. Потрібно оговорити важливість знайдених аналогій 3 урахуванням теми кроссенсу, знайти зв’язок з іншими темами, дисциплінами, фізичними явищами, зокрема природними.

Проблема, з якою часто зустрічаються автори кроссенсів, - це трактування зображень, які можуть бути не зовсім зрозумілі або досить загадкові. У такому випадку при використанні кроссенсу або його частин (пари картинок) можна давати короткі текстові підказки, підказки у вигляді інших картинок.

Робота 3 кроссенсами сприяє розвитку логічного, образного i асоціативного мислення, розвитку уяви, прояву нестандартного мислення, креативності й самовираження.

До розробки кроссенсів доцільно залучати студентів. Для цього можна використати їх досвід зі складання асоціативних ланцюжків, замінюючи слова картинками. Наприклад, обрати дві картинки, вихідну (першу) й узагальнюючу (дев'яту), та розмістити між ними ще сім картинок за правилами кроссенсу (асоціативних чи логічних зв’язків).

Приклад кроссенсу до теми «Сили в природі», розробленого студентами магістратури, приведено на рис. 2.
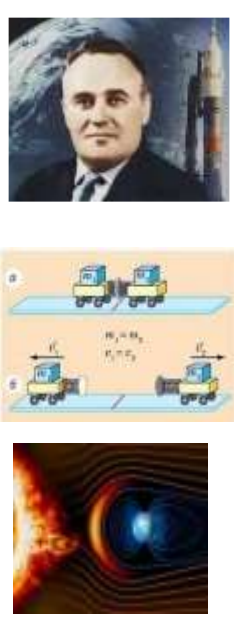
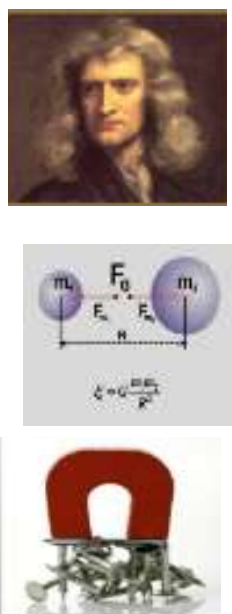
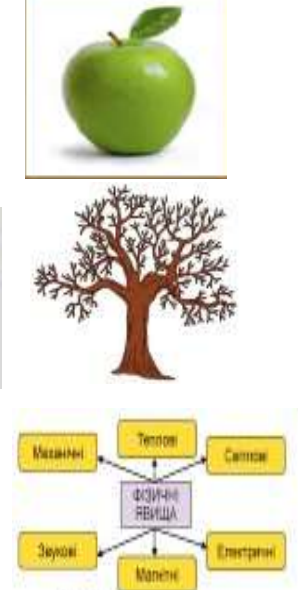
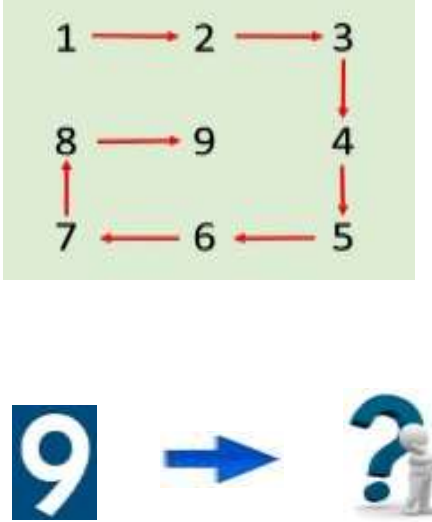

Рисунок 2. Кроссенс до теми «Сили у природі»

Цей кроссенс вони рекомендували використовувати в 9-му класі середньої школи після вивчення розділу «Рух і взаємодія. Закони збереження». 
Для підготовки студентів до розв'язання кроссенсів у процесі вивчення окремих тем та питань також можуть бути використані завдання на знаходження аналогій між двома картинками (рис. 3).

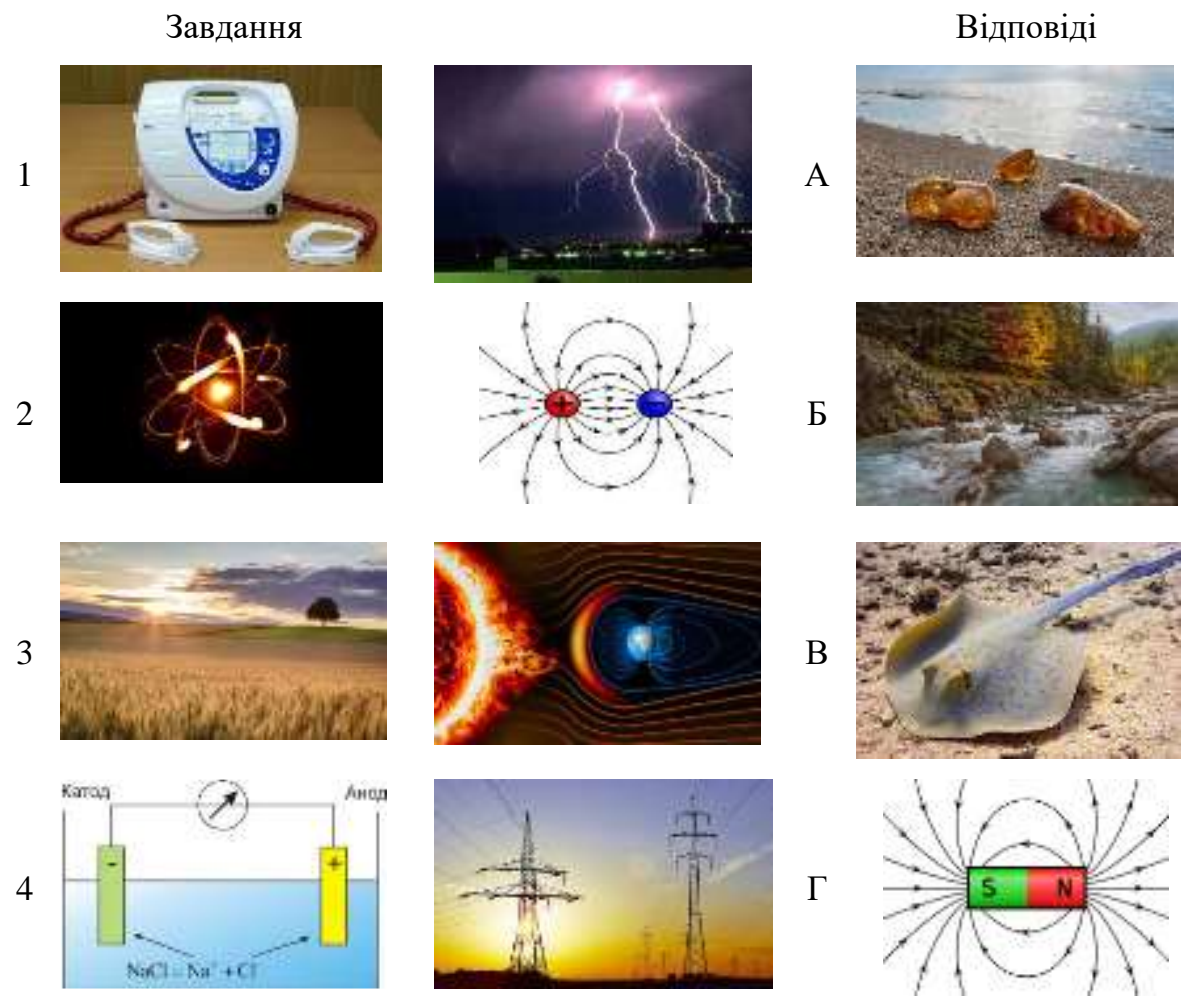

Рисунок 3. Завдання на встановлення відповідності

Тут у варіантах відповідей (А, Б, В, Г) потрібно знайти картинку, яка поєднує кожну пару $(1,2,3,4)$, представлену в завданнях. Слід зауважити, що відповіді повинні бути до кожної пари картинок. При цьому можливі різні варіанти поєднань. Студенти їх обговорюють і визначають найкращі варіанти.

Набір таких картинок може використовуватися як тестове завдання або для сумісного розв'язання на занятті.

Метод аналогій. Аналогія $є$ важливим засобом пізнання світу i загальновизнаним методом наукового дослідження. Однією з основних функцій методу аналогій є евристична, яка тісно пов'язана 3 асоціаціями (асоціативні аналогіï). Методи евристичного навчання - це методи, спрямовані на актуалізацію «прихованих» знань для створення нових продуктів (нових знань, ідей, досліджень тощо). На основі знаходжень аналогій з технічними об'єктами в іншій області, з біологічними об’єктами, з об’єктами і явищами неживої 
природи за допомогою групи евристичних прийомів здійснюється пошук нових ідей і рішень.

Застосування методу аналогій у навчанні - прийом, який використовується 3 давніх часів, починаючи з академії Платона і Ликея Аристотеля, де філософи представляли i обгрунтовували вчення, які переважно будувалися на міркуваннях і умовиводах, зроблених на основі аналогій. Проте, сьогодні метод аналогій ми можемо віднести до інноваційних методів навчання фізики, якій вимагає розробки нових підходів і нових методик [352]. Це пов’язано насамперед 3 новими можливостями, які відкриваються завдяки появі й розвитку мультимедійних засобів навчання, швидкого змінювання комп'ютерних технологій, які відігрівають все більшу роль у навчальному процесі.

Висновок за аналогією може бути як істинним, так і помилковим, тому необхідно обережно відноситися до застосування методу аналогій. Як і будь-яке припущення, умовивід, що базується на проведенні аналогій, вимагає ретельної експериментальної перевірки.

Водночас нестандартні випадкові аналогії можуть привести до креативних рішень, неочікуваних винаходів, оригінальних результатів.

Такий підхід покладено в основу синектики - одного 3 найбільш неординарних методів розвитку творчих здібностей i вирішення складних завдань [353]. Синектика - це процес пошуку і створення нових асоціативних зв’ язків.

Синектика у навчанні по суті $є$ мозковою атакою, мета якої полягає в рішенні задач шляхом підбору відповідних аналогій різного типу:

1. Пряма аналогія - даний об’єкт порівнюється 3 більш-менш схожим аналогічним об'єктом в природі або техніці.

2. Символічна аналогія - виявлення парадоксів i протиріч у звичних i зрозумілих фактах.

3. Особиста аналогія (емпатія) - дозволяє представити себе тим предметом або частиною предмета, про який йде мова в задачі. 
4. Фантастична аналогія - основний акцент робиться на символічний опис бажаного майбутнього або нереальних ситуацій.

Ця технологія була застосована на занятті 3 дисципліни «Інноваційні технології у навчанні фізики» на прикладі добору аналогій до поняття «електричний струм». Студентами було запропоновано наступні аналогії:

Прямі аналогї - течія води в річці, по трубах; водоспад, рух краплинок дощу з встановленою швидкістю; вітер; конвекція. Обговорювалися можливості застосування аналогії: аналіз поняття «стороння сила», ЕРС, порівняння причин, що обумовлюють рух (різниця потенціалів - різниця потенціальної енергії на різних висотах води, що «падає», різниця тисків, різниця температур); порівняння руху електронів по колу, що складається з провідників різного опору, зокрема різного поперечного перерізу, з рухом води по трубах різного діаметру; аналогії з рівнянням Бернуллі.

Символічні аналогї - словосполучення дискретна неперервність, суха річка, твердий вітер, електричний вітер, твердий дощ.

Особисті аналогї - я маленький електрон, що рухається між величезними іонами (металевими позитивно зарядженими кулями), які постійно коливаються, й постійно зіткається з ними. Але якась стороння сила змушує рухатися далі. При доборі аналогії застосовується метод «диспуту», на якому обговорюються, зокрема, способи зменшення опору, добір матеріалу провідників для використання в конкретних пристроях, з різною метою тощо.

Фантастичні аналогї - зводяться до вигадування різних варіантів проходження між чисельними перепонами на шляху до заповідної мети, наприклад, к спробам корабля (кораблів) пройти між Сциллою і Харибдою, що імітують іони у вузлах кристалічної решітки, які притягують електрони й забезпечують опір руху. Пропоновані варіанти розрізняються метою (причинами) руху (еквівалентом електрорушійної сили) та способами подолати перепони. Саме це стало переважно предметом обговорення за «круглим столом» після «мозкової атаки» з висунення ідей. 


\subsection{5. Технології ментальних та концептуальних карт}

До сучасних методів візуалізації інформації, що мають комп’ютерну реалізацію, відносяться конщептуальні карти (concept-maps) і ментальні карти (mind maps), створенню та застосуванню у навчальному процесі яких в наш час приділяється все більша увага. Ментальні карти також називають інтелекткартами, картами розуму, асоціативними картами.

Ментальна карта є графічним інструментом для організації та подання знань. Карти допомагають показати, як людина бачить взаємини між речами, ідеями, людьми. Концепт-карти є графи, причому вузлам графа (тобто, точкам) відповідають поняття, а ребрам графа - зв’язки між поняттями.

Карти розуму є багатоколірними, радіальними рисунками, які представляють в ієрархічному вигляді семантичні та інші співвідношення між елементами досліджуваного матеріалу.

На складанні і використанні ментальних карт базується освітня технологія, яка одержала назву технології майндмеппінгу (Mind Mapping).

Метод ментальних карт - одна з ефективних технік запам'ятовування, у основі якої лежить принцип «радіантного мислення», що базується на асоціативних розумових процесах. Основою радіантного мислення виступає певний об’єкт (основна концепція, ідея, тема, проблема), на основі якого виникають асоціації і будуються асоціативні ланцюжки: під-концепції першого, другого порядку й так далі.

Ментальна карта $є$ графічним відображенням процесу радіантного мислення на паперовому або електронному носії. У неї відображаються зв'язки між елементами або поняттями головної ідеї або предметної області, над якою ми працюємо або яку вивчаємо. Ці зв'язки можуть бути асоціативними, причинно-наслідковими, смисловими або іншими.

Інтелект-карти структуровані за аналогією пам’яті. При складанні таких карт виникає багатовимірне асоціативне мислення, що дозволяє бачити не тільки об'єкт навколишнього світу сам по собі, а у взаємоз'язку його 3 іншими об’ сктами [354]. 
Ментальні карти використовуються для візуалізації, структуризації i класифікації ідей, а також як засіб для навчання, організації, розв'язання задач, прийняття рішень, при написанні статей.

В освітньому процесі ментальні карти можуть бути застосовані як у професійній діяльності викладача (вчителя), так i в індивідуальній та колективній роботі студентів (учнів):

- при конспектуванні лекцій, книг, підручників;

- при підготовці викладача/студента до лекції, практичного заняття;

- для фіксування та структурування даних, систематизації наукової інформації;

- при підготовці презентацій, доповідей та виступів;

- при проведенні тренінгів, конференцій;

- при проведенні мозкового штурму;

- при плануванні та розробці проектів;

- при підготовці до екзамену, заліків, захисту кваліфікаційних робіт тощо;

- для перевірки знань студентів (учнів).

Характерними рисами ментальної карти є наступні:

- об'єкт вивчення/уваги зосереджений в центральному образі (стовбурі дерева);

- основні поняття, що зв'язані з центральним об'єктом, розходяться від нього у вигляді ліній (гілок);

- лінії позначаються ключовими словами або образами;

- другорядні ідеї теж зображені у вигляді ліній, які відходять від ліній більш високого порядку;

- лінії формують зв’язну вузлову систему.

Карта може необмежено рости i доповнюватися новими гілками, наприклад по мірі засвоєння навчального матеріалу.

Побудову карти знань 3 теми можливо здійснювати як виконання групового завдання, коли кожна група створює свою гілку відповідно до певного поняття або об’єкта, після чого вони об’єднуються в загальну карту знань. Такий 
вид роботи зручно використовувати при вивченні тем з великою кількістю понять і багатьма варіантами виконання робіт. Побудова карти знань може розглядатися і як індивідуальна підсумкова робота студента з заданої теми.

Одним 3 типових варіантів застосування інтелект-карт в навчальному процесі, який може бути раціонально використаний при самостійній роботі студентів, $\epsilon$ конспектування навчальних матеріалів 3 метою подальшого ефективного їх відтворення. Застосовуючи цей метод на всіх етапах майндмеппінга (формування масиву елементів майбутньої карти, графічне їх оформлення, встановлення логічних і асоціативних зв'язків між ними), студент при наявності належних навичок отримує індивідуалізований, більш зручний конспект.

При сучасному, компетентнісно-орієнтованому підході до навчання у ЗВО важливу роль відіграє діяльнісна компонента. Незважаючи на наявність відповідних нормативних вимог і рекомендацій в цьому питанні, насичення освітнього процесу практико-орієнтованими засобами та методиками навчання поки недостатня. Тому будь-які підходи, націлені на розвиток і придбання студентом практичних навичок по його майбутньої спеціальності, є цінними.

У випадку педагогічного ЗВО засвоєння технології побудови ментальних карт є необхідною складовою фахових компетентностей майбутніх вчителів та викладачів фізики. Тут реалізується й вимога набуття здатності працювати у команді, зокрема, віддаленого спільного складання інтелект-карт за допомогою веб-сервісів, й оволодіння електронними методами побудови ментальних карт. В результаті ментальні карти входять до складу електронних освітніх ресурсів; карти, створені студентами включаються в їх електронні портфоліо.

Сьогодні існує багато онлайн-сервісів для створення ментальних карт та спеціалізованих програмних додатків під різні платформи, що дозволяють економить час і ресурси. Всі вони характеризуються індивідуальними специфічними можливостями і дозволяють автоматизувати операції створення ментальних карт та представлення їх в електронному вигляді. На таких картах може бути забезпечена можливість додавання відео матеріалу, наприклад, за 
допомогою сайту YouTube. Зручною функцією є додавання активних посилань, при переході через яке користувач зможе отримати всю необхідну інформацію.

Coggle.it - безкоштовний сервіс, що дозволяє створювати красиві онлайнкарти.

Тут можна створювати будь-яку кількість гілок, викривляти їх, змінювати кольори, і переміщати елементи. Перетягування елементів здійснюється за заголовки, а не за тим, як це інтуїтивно хочеться зробити. На безкоштовному акаунті кількість карт необмежена. При створенні ментальної карти на цьому сайті можна використовувати надписи, формули, рисунки, посилання на віртуальні досліди. Можна поділитися картами в соцмережах, а також працювати над ними спільно зі студентами. Можна вбудувати карту в сайт або блог, а також зберегти іiі у вигляді PNG або PDF-файлу. $€$ функція збереження історії всіх змін, що дозволяє в будь-який момент повернутися до попередніх версій карти. Для використання Google потрібен обліковий запис в Gmail.

Mind42.com - характеризується простою у застосуванні, але має скупу функціональність на безкоштовному акаунті. Не можна вільно переміщувати елементи і редагувати стилі. Неможливо додавати картинки з файлів, додаються тільки посилання. Немає колірних схем і шаблонів. Потрібна реєстрація перед доступом до ресурсу.

Mindomo.com - доступні кілька шаблонів для складання карт. Можна вибирати колірні схеми-шаблони в один клік, прикріплювати до елементів картинки, іконки, завдання, коментарі. Дозволяє створювати карти, що містять фотографії, малюнки, звук, відео; можна додавати посилання. На безкоштовному акаунті діють обмеження.

Bubbl.us - дуже простий онлайн-інструмент. Дозволяє додавати посилання на відео та віртуальні лабораторії, легко ділитися своїми інтелекткартами з іншими людьми в режимі реального часу. Можна працювати без реєстрації, скачати створене як зображення.

XMind - крос-платформена програма, що дозволяє створювати діаграми, схеми, складні структури, щоб систематизувати і наочно уявити потік ідей i 
планів. Одна 3 найпопулярніших програма для складання ментальних карт. $\mathcal{C}$ безкоштовна версія 3 урізаними можливостями i платна 3 розширеним функціоналом.

Mindmeister.com - дозволяє прикріплювати іконки до елементів карти, виділяти окремі гілки своїм особливим кольором. На безкоштовному акаунті можна створити три карти. Сервіс Mindmeister доцільно використовувати для розробки карт, які створюються в процесі навчання теми У ньому можливо приховувати необхідні гілки, змінювати масштаб великої ментальної карти. Так само в ньому є можливість експорту карти в різні формати. При цьому можна зберігати не тільки всю ментальну карту цілком, але й окремі ії фрагменти, 3 якими студенти вже познайомилися і засвоїли. При включенні до карти посилань на комп'ютерні симуляції можна переходити по них і виконувати віртуальні роботи, розв’язувати задачі. Приклад такої карти, розробленої студентами магістратури до практичного заняття 3 теми «Побудова зображень в тонких лінзах» за допомогою ресурсу Mindmeister.com приведено на рис. 4.

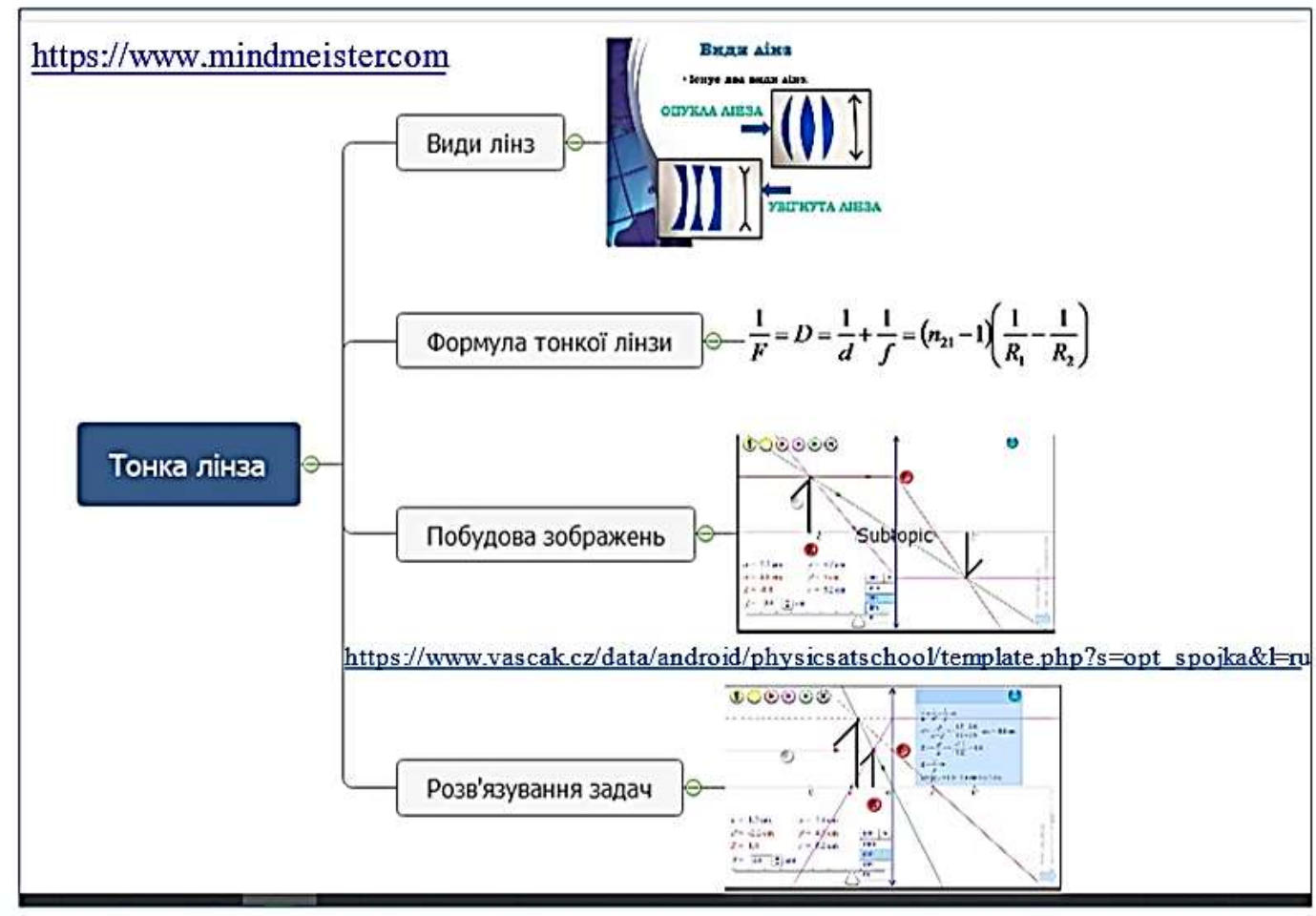

Рисунок 4. Ментальна карта до підтеми «Тонка лінза» 
Така карта також може бути використана при вивченні теми «Лінзи. Оптична сила й фокусна відстань лінзи. Формула тонкої лінзи. Отримання зображень за допомогою лінзи» у 9-му класі середньої школи.

\section{Методика застосування ментальних карт у навчальному процесі}

Можна виділити кілька моделей створення і використання ментальних карт в навчальному процесі залежно від мети.

1. Будується велика ментальна карта, яка захоплює весь досліджуваний розділ. До цієї карти входять всі теми, які необхідно вивчити студентам. Кожна гілка ментальної карти відповідає певній темі. Таку карту доцільно будувати або демонструвати за допомогою інтерактивної дошки.

2. Розробляються карті для кожного заняття з кожної теми розділу. На протязі вивчення теми ментальна карта поступово розкривається від центрального поняття, до гілок. Найефективніше в даному випадку, використовувати на заняттях вже готові ментальні карти, розроблені викладачем.

3. Використовуються готові ментальні карти, у які входить не теоретичний матеріал, а питання, на які повинні відповісти студенти по ходу знайомства 3 новою темою. В центрі карти при цьому розташовується головне питання, далі ментальна карта розбивається на головні гілки, в яких теж присутні питання по темі. Потім головні гілки розбиваються підгілки і так далі. У процесі навчання студенти поступово відшукують відповіді на ці питання.

4. Студенти розбиваються на міні-групи, в яких протягом усього заняття, будують свою власну ментальну карту і надають результат в кінці кожного заняття.

5. Протягом заняття, знайомлячись 3 новим матеріалом, студенти розробляють ментальну карту, працюючі в міні-групах над своєю гілкою і після закінчення формування всіх гілок, їх об’єднують в одну ментальну карту. Отриману ментальну карту обговорюють, коригують. Якщо заняття проводиться в аудиторії, процес об’єднання гілок має відбуватися на інтерактивній дошці.

Порядок дій і рекомендації до самостійного створення ментальної карти.

1. Визначте тему, призначення, мету й завдання, які хочете вирішити за допомогою карти. 
2. Запишіть першорядну думку, ідею або проблему, яка відіграватиме роль центрального образу (стовбура), наприклад, це може бути тема карти.

3. Залежно від мети визначте ключові слова (напрямки, підтеми, категорії, діï), які безпосередньо пов'язані з темою карти. Вони відповідатимуть першому рівню «гілок дерева». Виконання цього завдання студентами передбачає попередній збір та обробку та систематизація матеріалу (вивчення інформації і 110 аналіз) і класифікацію ключових слів на основні і похідні поняття для кожного рівня.

4. Візьміть окремий напрямок і почніть опрацьовувати його, розкриваючи зміст і доповнюючи другорядними (похідними) напрямками (гілками) наступного рівня.

5. Проробить таким чином усі вибрані напрямки.

6. Оберіть спосіб створення ментальної карти (малюнок олівцями, використання певного онлайн-сервісу) та спосіб, яким будете представляти обраний напрямок (елемент) у ментальній карті (слово, формула, малюнок, фотографія, умовне позначення, відеоролік). Тобто цей пункт може передбачати підбір малюнків і фотографій, формул до відібраного матеріалу.

7. Поєднайте все в одній ментальній карті, використовуючи при необхідності лінії (стрілки), які з'єднують окремі елементи карти (горизонтальні зв'язки в концептуальній карті).

Ментальна карта не є строгою, її наповнення, кількість гілок та рівнів можуть визначатися автором, але існує ряд базових правил, дотримання яких, дозволяє одержати найбільший ефект від застосування методу:

- центральний образ повинен виділятися на тлі інших елементів інтелекткарти;

- не слід використовувати довгих речень, це засмічує карту й відволікає від суті; формулювати думку краще в одному - трьох словах.

- у карті потрібно використовувати не тільки слова, а й графічні образи, малюнки, завдяки чому задіються декілька кортикальних здібностей нашого 
мозку одночасно (мовна i візуальна), що сприяє більш кращому запам’ ятовуванню;

- при створенні карти слід дотримуватись ієрархії думок, зв’язків, важливі і другорядні думки не повинні перемішуватися на одному рівні, це ускладнює роботу і може заплутати як творця, так і глядача.

Приклад розробки з певної теми загальної фізики та створення на її основі ментальної карти приведено у табл.1 та на рис. 5.

Карта розроблена та створена на практичному занятті спільними зусиллями викладача і студентів магістратури. Для побудови карти використано сервіс https://coggle.it.

Спільна робота з викладачем підсилює інтерес студентів до теми, підвищує мотивацію, що дозволяє їм краще засвоїти і запам’ятати навчальний матеріал, що викладається. Викладач допомагає їм сконцентрувати увагу на найважливішому, тим самим підвищується ефективність навчання.

Ця карта може використовуватися при вивченні розділу «Молекулярна фізика та термодинаміка» викладачем при представленні теми «Дифузія» та надання студентам інформації про те, що саме потрібно опанувати 3 представленої теми.

Карта, яка виконана студентами самостійно, дає можливість виділити неясні елементи, які необхідно освоїти або уточнити.

Концептуальні карти незважаючи на схожість 3 інтелект-картами відрізняються від них за багатьма аспектами. Концептуальні карти характеризують ясні відносини між описаними ідеями, вони більш структуровані, ніж інтелект-карти. Концептуальна картографія дозволяє бачити більш складні відносини між ідеями: тут їх концепти представлені не тільки ієрархічними зв'язками, але і частиною системи, пов'язаної 3 іншими концепціями, через зв’язки вхідні та вихідні. На відміну від ментальних карт, концептуальні карти зосереджені не тільки на одному слові або ідеї, а можуть з’єднувати кілька слів або ідей. Для них характерна наявність так званих «горизонтальних» або «перехресних» зв’ язків. 
Таблиця 1. До побудови ментальної карти

\begin{tabular}{|c|c|c|}
\hline \multicolumn{3}{|c|}{ Тема (ядро, стовбур) ментальної карти - Дифузія } \\
\hline 1-й рівень: & 2-й рівень & Додаткове позначення \\
\hline \multirow{5}{*}{ види дифузії } & стаціонарна & \multirow{5}{*}{-} \\
\hline & нестаціонарна & \\
\hline & самодифузія & \\
\hline & взаємна дифузія & \\
\hline & термодифузія & \\
\hline \multirow{6}{*}{$\begin{array}{c}\text { основні } \\
\text { характеристики }\end{array}$} & градієнт концентрацій & $d n / d x$ \\
\hline & градієнт густини & $d \rho / d x$ \\
\hline & \multirow{2}{*}{ дифузійний потік } & $I=d N /(d S \cdot d t)$ \\
\hline & & $M=d m /(d S \cdot d t)$ \\
\hline & коефіцієнт дифузії & $D$ \\
\hline & $\begin{array}{l}\text { коефіцієнт дифузії ідеального газу, } \\
\text { самодифузія }\end{array}$ & $D=\bar{v} \bar{\lambda} / 3$ \\
\hline \multirow[b]{2}{*}{ рівняння дифузії } & дифузійний потік & $M=-D \frac{d \rho}{d x}, \quad I=-D \frac{d n}{d x}$ \\
\hline & $\begin{array}{c}\text { маса (кількість молекул), що } \\
\text { переноситься }\end{array}$ & $\begin{array}{l}m=-D \frac{d \rho}{d x} \cdot d S \cdot d t \\
N=-D \frac{d n}{d x} \cdot d S \cdot d t\end{array}$ \\
\hline \multirow{5}{*}{ дифузія у природі } & харчування рослин & \multirow{5}{*}{ Відеоролік } \\
\hline & $\begin{array}{c}\text { проникнення кисню з крові в тканини } \\
\text { людини }\end{array}$ & \\
\hline & дихання тварин & \\
\hline & $\begin{array}{c}\text { відносна однорідність земної } \\
\text { атмосфери }\end{array}$ & \\
\hline & відчуття запахів & \\
\hline \multirow{5}{*}{$\begin{array}{c}\text { застосування } \\
\text { дифузії }\end{array}$} & фарбування тканин & \multirow{5}{*}{ Відеоролік, картинки } \\
\hline & виготовлення сплавів & \\
\hline & зварювання металів & \\
\hline & $\begin{array}{c}\text { дифузне насичення вуглецем залізних і } \\
\text { сталевих поверхонь для підвищення } \\
\text { твердості } \\
\end{array}$ & \\
\hline & дифузія в медицині & \\
\hline \multirow{5}{*}{$\begin{array}{l}\text { методи визначення } \\
\text { коефіцієнта дифузії }\end{array}$} & $\begin{array}{c}\text { застосування випаровування } \\
\text { (лабораторна робота) }\end{array}$ & $\begin{array}{c}\text { Посилання на інструкцію до } \\
\text { роботи }\end{array}$ \\
\hline & використання радіоактивних ізотопів & \multirow[b]{4}{*}{$\mathrm{C}_{\mathrm{C}}$} \\
\hline & $\begin{array}{c}\text { локальний рентгеноспектральний } \\
\text { аналіз }\end{array}$ & \\
\hline & метод електрон-діркових переходів & \\
\hline & $\begin{array}{c}\text { побудовані на вимірюванні зміни } \\
\text { структури }\end{array}$ & \\
\hline $\begin{array}{l}\text { зв’ язок зі шкільним } \\
\text { курсом фізики }\end{array}$ & $\begin{array}{c}\text { Фізика: підруч. для } 7 \text { кл. загальноосвіт. } \\
\text { навч. закл. / [В. Г. Бар'яхтарта ін.] § } 2 . \\
\text { Будова речовини. Молекули. Атоми }\end{array}$ & $\begin{array}{l}\text { https://www.ranok.com.ua/resour } \\
\text { ces/files/pdf/Phisica_7_Uch.pdf }\end{array}$ \\
\hline $\begin{array}{l}\text { міжпредметні } \\
\text { зв'язки }\end{array}$ & $\begin{array}{c}\text { Калініченко Ю.Ю. Розвиток поняття } \\
\text { дифузії в шкільному курсі хімії та } \\
\text { біології. }\end{array}$ & $\begin{array}{l}\text { http://www.rusnauka.com/12_E } \\
\text { NXXI_2011/Chimia/2_85494.do } \\
\text { c.htm }\end{array}$ \\
\hline
\end{tabular}




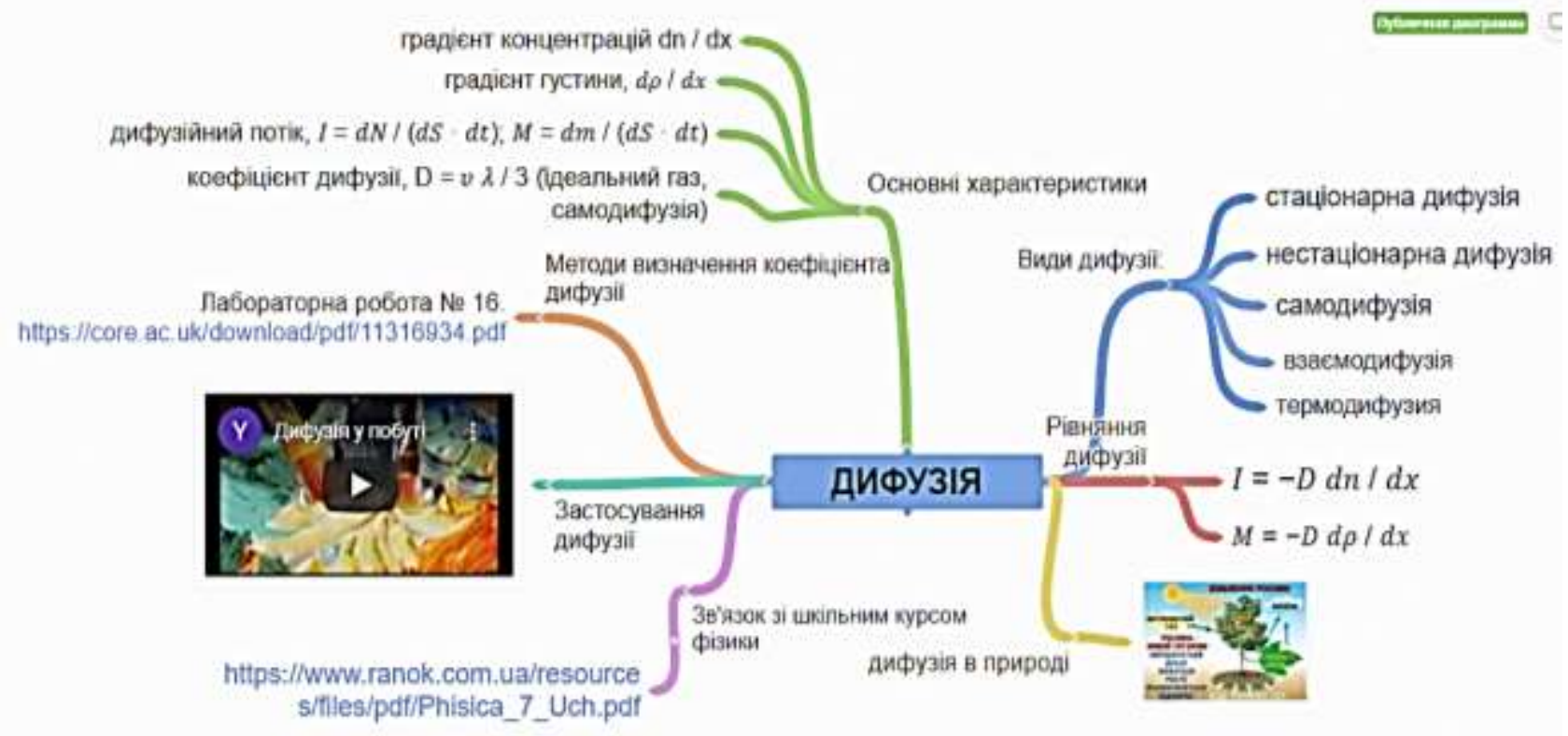

Рисунок 5. Ментальна карта теми «Дифузія»

Зазвичай концептуальні карти організовані ієрархічно. Це означає, що найбільш загальні і всеосяжні концепції розміщені у верхній частині карти. Ti, які більш специфічні, розташовані під ними. Відповідно, ієрархічні концептуальні карти читаються зверху вниз. Однак, структура концептуальної карти не обмежується цією структурою, вона може приймати й вільну форму починаючи з центру і поширюючись назовні.

\subsection{6. Віртуальний експеримент та його роль і місце в навчанні фізики}

Експеримент є однією з важливих складових наукових досліджень. На науковому експерименті базується навчальний фізичний експеримент, який $є$ основою вивчення фізики у закладах освіти різного рівня.

Поняття «експеримент» зазвичай визначають як проведення на реальному обладнанні у визначених умовах серії дослідів для спостереження за станом об'єкта дослідження, які дозволяють стежити за його змінами і відтворювати їх кожний раз під час повторення дослідів. Такий експеримент називають реальним або натурним.

Водночас часто процес пізнання передбачає абстрагування, ідеалізацію природних явищ, побудову ідеалізованих моделей, які не враховують усі властивості, ознаки, зв'язки між об'єктами. Прикладами такої ідеалізації об'єктів $\epsilon$ моделі матеріальної точки, ідеального газу, абсолютно твердого тіла, 
абсолютно чорного тіла. На таких ідеальних моделях грунтується багато фізичних теорій: молекулярно-кінетична теорія ідеального газу, теорія ідеальної рідини, випромінювання абсолютно чорного тіла тощо, при побудові яких зазвичай використовується так званий мислений експеримент, якій також називають уявним.

Уявний (мислений) експеримент як вид діяльності людини належить до теоретичного, але має риси реального (натурного), бо в ньому виникає перебіг певного фізичного явища. Термін «мислений експеримент» уособлює, таким чином, поєднання ідеального та реального.

У ході уявного експерименту можливо будування моделей об'єктів або явищ, що з різною глибиною відображають їх сутність, вивчення окремих сторін явищ, з'ясування їх фізичного змісту, дослідження на моделях залежності між параметрами об'єкту, характеристиками процесу, забезпечувати візуалізацію процесів у віртуальному середовищі. Такий експеримент одержав назву віртуального. Хоча єдиного підходу до визначення поняття «віртуальний експеримент» не існує. Часто віртуальним називають будь-який мислений експеримент (дифракція електронів на двох щілинах), іноді - експеримент, здійснений за допомогою спрощеної моделі реального приладу, або у якому застосовано умовну (механічну) модель процесу (механічна модель розподілу молекул за швидкостями). Але останнім часом переважає поняття віртуального експерименту як візуалізованого за допомогою комп'ютерних технологій.

Комп'ютерне моделювання у системі навчального експерименту може бути запроваджене в трьох напрямах:

1) як самостійна форма експерименту;

2) як доповнення до реального експерименту, коли частина дослідження проводиться віртуально (наприклад, обробка результатів, графічна інтерпретація), або, у випадку, коли деякі роботи проводяться віртуально, а деякі - реально;

3) як невід’ємна частина експериментального дослідження, інтегрована із реальним (комплекти обладнання у поєднанні з ІКТ). 
Перший підхід $\epsilon$ доцільним у тому випадку, коли проведення експерименту обмежено можливостями існуючого лабораторного обладнання. Другий підхід дозволяє значно розширити тематику експериментальних досліджень, але для отримання результатів експерименту та їх аналізу найбільш достовірні дані будуть отримані за умови комплексного проведення дослідження.

Інтеграція віртуального та реального фізичного експерименту, їх обгрунтований взаємозв'язок, дасть можливість студенту вивчати навколишній світ, його закони та закономірності розвитку на більш високому рівні, одночасно стимулюючи самостійну пізнавальну діяльність, творчість, саморозвиток та самоосвіту. Для успішної реалізації названих аспектів необхідне подальше вдосконалення і розвиток методичних аспектів упровадження засобів IКТ та створення на їх основі сучасних навчально-методичних комплексів.

Сьогодні віртуальний експеримент стає невід’ємною складовою практично будь-якої навчально-дослідної діяльності здобувачів освіти, що віддзеркалює тенденції поступового переходу до дистанційних форм навчання. Базою для впровадження таких методів навчання можуть слугувати віртуальні лабораторії, мультимедійні та інтерактивні програми, навчальні ігри та багато іншого.

Використовуючи навчальні комп'ютерні моделі можна подати досліджуваний матеріал більш наочно, продемонструвати його нові й несподівані сторони невідомим раніше способом, що, в свою чергу, підвищує інтерес студентів до досліджуваного предмета і сприяє поглибленню розуміння навчального матеріалу.

Навчальний фізичний експеримент може бути використаний на різних етапах навчання та 3 різною дидактичною метою. Система навчального експерименту охоплює такі його види: демонстраційні досліди, роботи фізичного практикуму; експериментальні задачі, позааудиторні досліди [355].

Сучасні електронні засоби дозволяють гармонійно поєднати дидактичні принципи 3 науковістю матеріалу, зрозуміло описувати експеримент i відтворювати досліджуване фізичне явище у довільному масштабі часу, 
проводити імітаційне моделювання явищ, недоступних для класичних методів спостереження, таких, як процеси мікросвіту та космосу, візуалізувати уявний експеримент тощо.

За допомогою таких віртуальних моделей (симуляцій) можна не тільки спостерігати, а й «управляти» процесом. Так, наприклад, симуляція «Боровська модель атому» допомагає проілюструвати перехід атомів між стаціонарними орбітами при поглинанні або випромінюванні кванта енергії. Модель може бути застосована як демонстраційна на традиційній лекції, пропонована студентам для самостійного спостереження, та використана для створення проблемної ситуації (рис. 6).

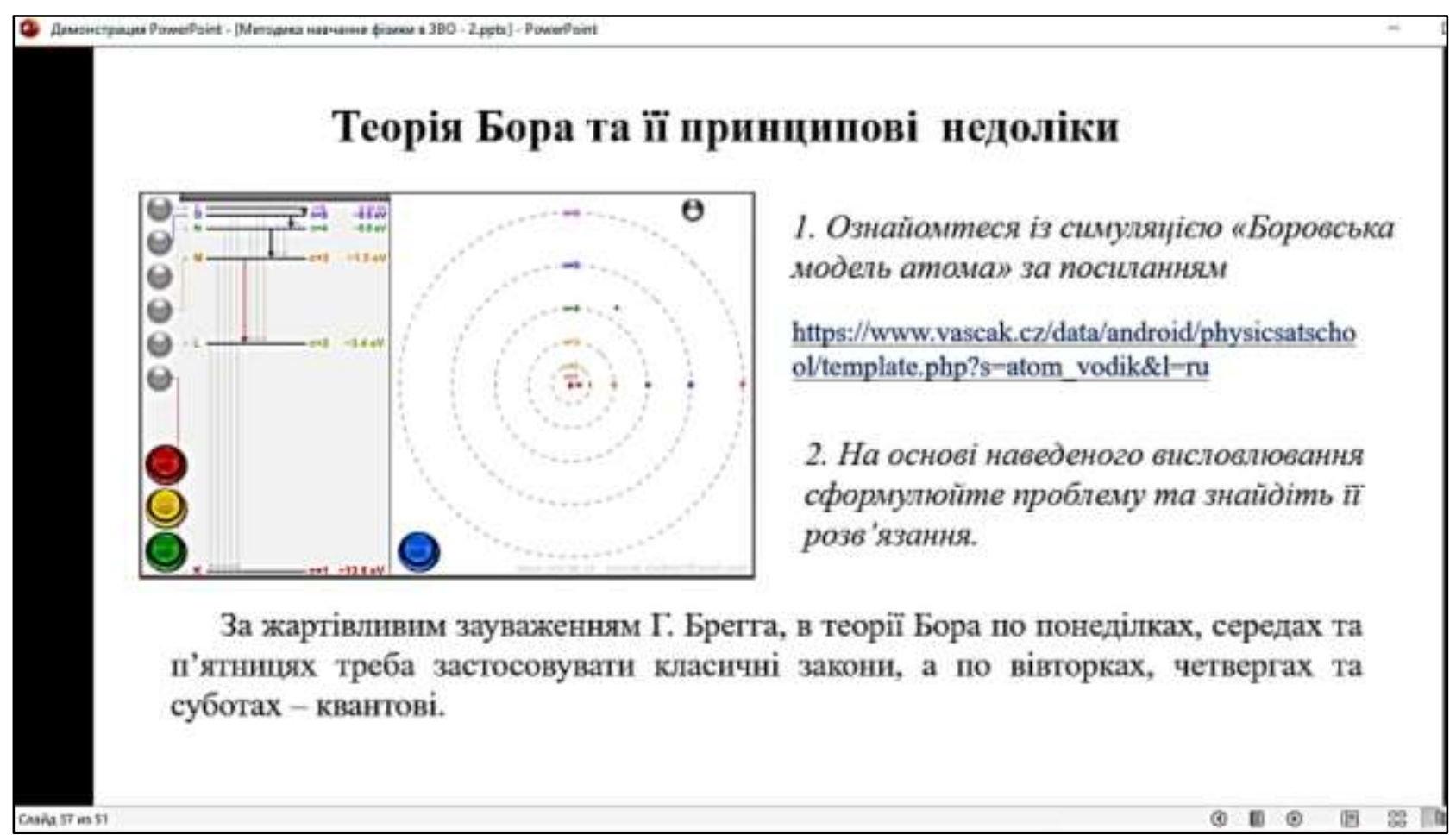

Рисунок 6. Теорія Бора та іï̈ принципові недоліки.

Фрагмент презентації курсу «Методика навчання фізики в 3ВО»

Багато комп’ютерних симуляцій дозволяють на тільки демонструвати та аналізувати фізичні явища та процеси, а й складати та розв'язувати різні типи задач: якісні, графічні, аналітичні; розробляти тестові завдання [356].

Різноманітні програми, що дозволяють проводити як фізичний експеримент, так і лабораторну роботу з фізики, містять велику кількість задач, умова яких побудована на даних експерименту. Змінюючи умови експерименту 
можна змінювати умови задачі. Програми дозволяють перевірити правильність розв'язання задачі за будь-яких умов експерименту.

Студенти краще засвоюють матеріал, якщо вони не тільки розв'язують запропоновані їм готові задачі, а й навчаються їх складати самостійно, набуваючи компетентності, необхідні майбутнім учителям і викладачам фізики. Так при вивченні теми «Фотоефект» можна використати відповідну симуляцію й запропонувати студентам скласти до неї задачі різного рівня складності (рис. 7).

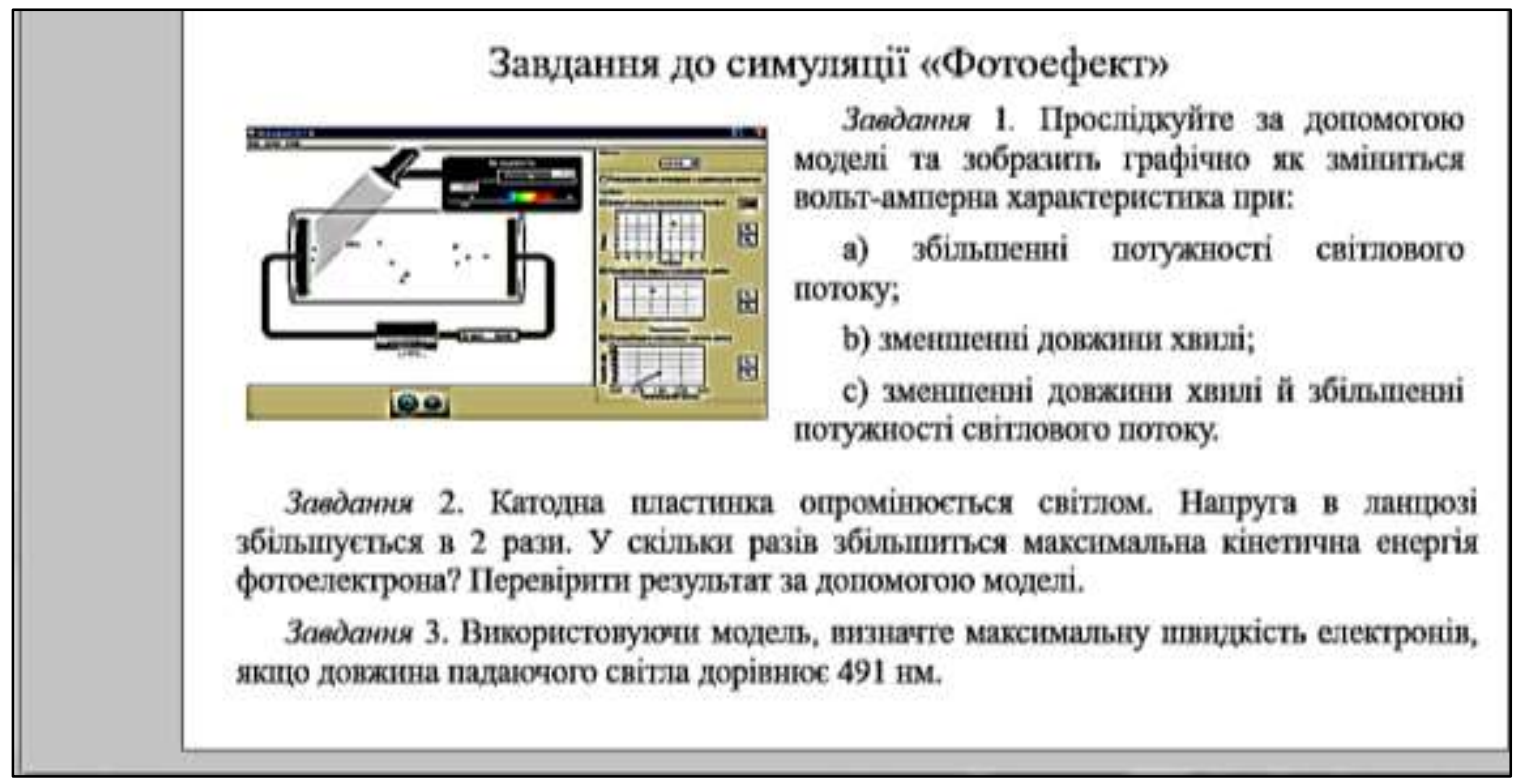

Рисунок 7. Фрагмент презентації, розроблений студентами при виконанні проєкту «Явище фотоефекту в навчанні фізики»

Симуляція «Інтерференція хвиль» порталу Phet.Colorado (https://phet.colorado.edu) дозволяє проводити аналогію між інтерференцією механічних поверхневих та звукових хвиль і електромагнітних (світлових) хвиль, аналізувати залежність інтерференційної картини від виду та розміру об'єктів, на яких відбувається дифракція, складати завдання до практичних занять з відповідних тем, зокрема, із залученням до складання студентів (рис. 8). 


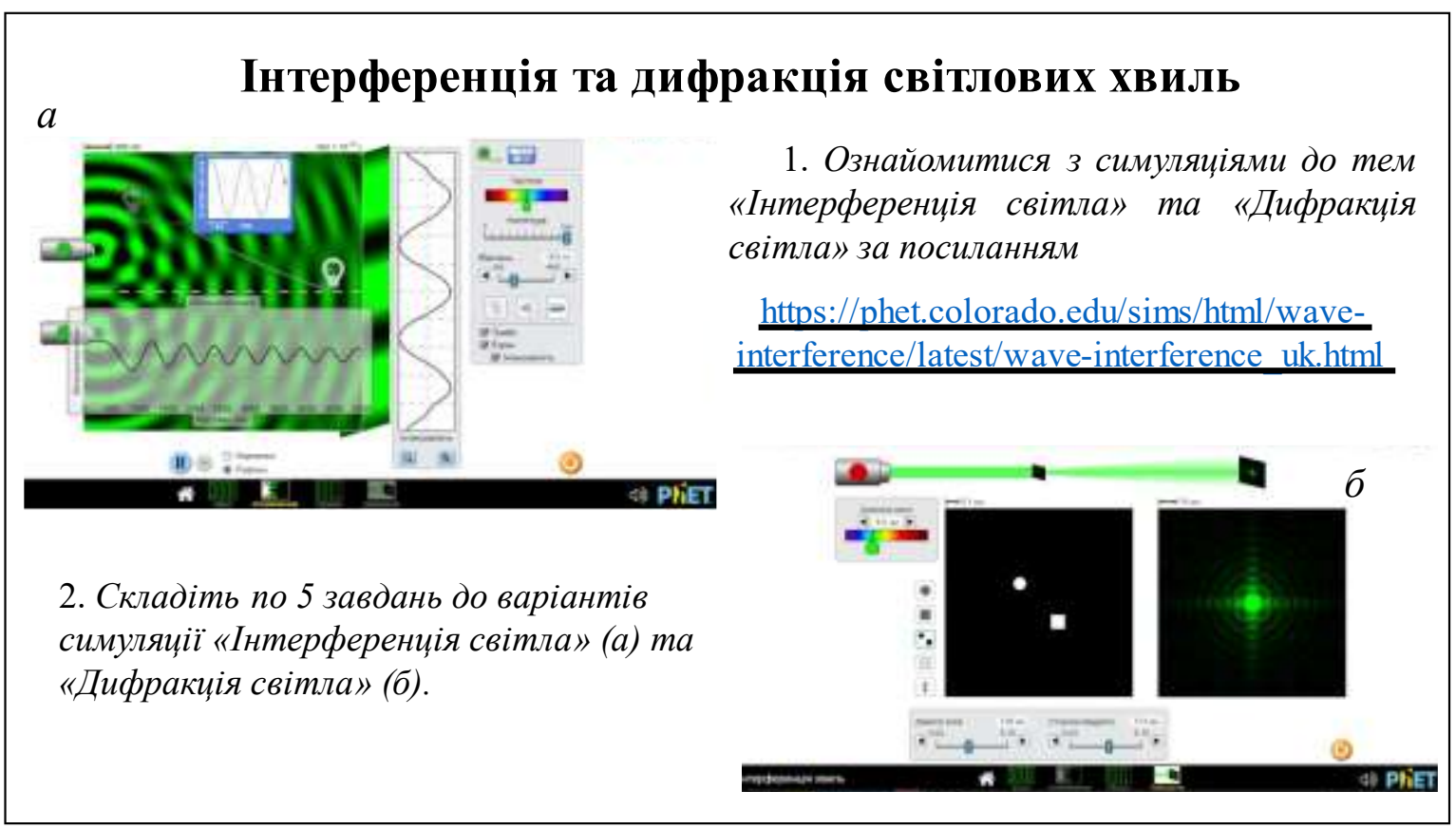

Рисунок 8. Інтерференція та дифракція світлових хвиль.

Фрагмент презентації курсу «Методика навчання фізики в 3ВО»

При демонстрації вказаних симуляцій може бути встановлений зв'язок зі шкільним курсом фізики, проведено порівняння пояснення процесів, що ілюструються симуляціями, при навчанні відповідних тем у школі та вищому навчальному закладі.

\subsection{7. Технологія перевернутого навчання (flipped learning)}

Єдиного визначення технології перевернутого навчання не існує. Його можна визначити як «педагогічний підхід, при якому пряме навчання переміщається 3 простору групового навчання в простір індивідуального навчання, а результуючий груповий простір трансформується в динамічну інтерактивну середу навчання» [357]. Роль викладача у такому просторі зводиться до спрямування тих, хто навчається, мотивування студентів до самостійного пошуку знань за межами аудиторії, формування навичок не тільки шукати інформацію, а й перевіряти іiі достовірність, аналізувати, критично осмислювати. Роль студента при цьому переходить від пасивного одержувача до активного конструктора знань [358].

Перевернуте навчання поділяється на 3 фази: Pre-Phase (до проведення аудиторних занять), face-to-fase (активне навчання в аудиторіï), Post-Phase - (після 
аудиторної роботи, рефлексія), які можуть бути реалізовані 3 використанням електронних навчальних курсів на основі технології мікронавчання [359].

Виділяють декілька форм перевернутого навчання.

1. Класична модель перевернутого навчання, яка передбачає:

- попереднє ознайомлення студента 3 матеріалом, якому буде присвячено майбутнє заняття; переважно матеріал готує або рекомендує викладач (опорний конспект лекцій, підрозділ підручника, презентація, подкасти, водкасти та інші форми представлення інформації);

- обговорення вивченого матеріалу в аудиторії 3 поясненням складних моментів, відповіді викладача на питання;

- закріплення теоретичних знань на практичному занятті, набуття практичних вмінь;

- виконання завдань для самостійної роботи, оцінювання засвоєння нового матеріалу.

Отже навчання за цією моделлю продовжує нагадувати традиційну систему освіти.

2. Основними етапами «просунутої» моделі перевернутого навчання $є$ наступні:

- попередня підготовка, в ході якої викладач лише задає тему, а студенти самостійно здійснюють пошук інформації та індивідуально або поєднуючись у міні-групи готують іiі представлення на майбутньому занятті;

- розміщення студентами підготованого матеріалу (тез, слайдів) на спільній електронній платформі, що дає можливість усім студентам та викладачу заздалегідь з ним ознайомитися й забезпечує моніторинг самостійної роботи кожного студента;

- презентація підготованого матеріалу в аудиторії (на занятті) з обговоренням i аргументованим аналізом роботи кожної групи, що може відбуватися в різних формах, наприклад виступ представника від кожної групи с подальшим обговоренням усіх пропозицій за «круглим столом». 
3. Системна або комбінована модель перевернутого класу, яка може розглядатися як комбінування перших двох моделей. Застосування цієї моделі передбачає наступні етапи:

- дистанційний етап: студенти працюють самостійно або в міні-групах, за наданими завданнями або проблемною ситуацією здійснюють пошук і аналіз необхідної інформації, пропонують варіанти рішень;

- представлення знайденої інформації і варіантів розв'язання завдань в аудиторії, аналіз матеріалу й пропозицій під керівництвом викладача, оцінювання переваг і недоліків кожного з пропонованих рішень;

- другій дистанційний етап, в ході якого студенти в міні-групах аналізують та узагальнюють досвід сумісної діяльності із зазначеної проблеми;

- заключний етап в аудиторії, на якому підводяться підсумки роботи, обговорюються можливості застосування одержаних знань та результатів в інших ситуаціях.

Дана модель перевернутого навчання є педагогічним підходом, найбільш наближеним до реальності, оскільки в повсякденному і професійному житті дуже часто доводиться приймати рішення в умовах невизначеності або ризику.

Різні моделі перевернутого класу дозволяють використовувати більш широкий арсенал форм контролю знань, вмінь та компетентностей студентів, відбувається оцінювання використаних підходів для пошуку інформації, якості самої інформації, внеску кожного в колективне знання, здатності до комунікації в групи, ефективності взаємного навчання, оцінка діяльності кожного його однолітками, самооцінка.

Ефективність методу перевернутого навчання щодо підвищення якості, забезпечується завдяки його гнучкості, можливості використовувати в кожній конкретній ситуації той варіант, який найбільшою мірою відповідає цілям викладача. Проте перевернуте навчання передбачає значне збільшення обсягу самостійної роботи студентів, що вимагає наявності методичного та матеріальнотехнічного забезпечення процесу навчання, створення інформаційного простору педагога і студентів. Зокрема, вивчення теоретичного матеріалу здійснюється 
студентами самостійно через роботу з онлайн-ресурсами, що вимагає забезпечення постійного доступу в Інтернет.

Результативність навчання залежить від якості використовуваних матеріалів. Під час їх розробки слід брати до уваги ізольованість студента, який навчається дистанційно. Матеріали повинні мати необхідні пояснення, бути привабливими, всі труднощі процесу вивчення повинні заздалегідь передбачатися авторами.

Поряд 3 навчальним текстом або відеоматеріалом викладач може представити структурно-логічну схему теми, що вивчається, й запропонувати студентам заповнити пробіли, самостійно скласти опорні конспекти, розробити ментальну карту, заповнити певні таблиці [360]. Потім на занятті відбувається обговорення варіантів, які пропонують різні студенти, i формулювання правильного, найбільш ефективного розв’язання. Звичайно, підготовка методичного забезпечення для таких різноманітних форм навчальної роботи вимагає від викладачів значних витрат часу та креативного підходу.

Ефективність застосування методу також залежить від рівня мотивації, самостійності, свідомості, активної участі в навчанні, до чого студенти не завжди готові. Таким чином, виникає потреба використання інноваційних технологій i методів навчання, які дозволяють вивчати матеріал в процесі самостійної пізнавальної діяльності студента при ключової і організуючої ролі викладача.

Перевернуте навчання перетинається 3 різними підходами, такими як особистісно-орієнтоване навчання, системно діяльнісний підхід проблемне навчання, зокрема за методом Case-study, тощо.

Всі підходи дозволяють за допомогою опори на систему взаємопов'язаних понять, ідей, способів і дій забезпечувати та підтримувати процеси самоорганізації, самовдосконалення, самореалізації, самопрояву суб’єкта пізнавальної діяльності, усвідомлення цінності особистісного сенсу наукового мислення та значущості метазнань як основ духовно-моральної та інтелектуальної культури професійного менталітету, соціалізації особистості.

Проектування нових способів отримання знань та рішення педагогічних проблем є основою інноваційної діяльності викладача. 